\title{
SENSORY, CHEMICAL AND MICROBIOLOGICAL EVALUATION OF SMOKED HERRING FISH
}

\author{
Abd El-Hafiez, E. M. E.** \& Amany, M. Salem* \\ - Department of Food Control, Faculty of Vet. Med. Benha Universily \\ •Animal Healch Rescarch Insllcule. Alexandria branch*
}

\begin{abstract}
Evaluation of sensory. chemical and microblological status of smoked herring sold in supermarkets in Egypt was carrled out. Twenty fue random samples of smoked herthing were taken and transferred direclly to t:ie laboratory under aseptic condltions with a minimum of delay. The samples were subjecled lo sensony. chemical and microblological examinations. The obtained results revenled that $16 \%$ of samples were rejected due to higher lotal bacterial count; 44\% rejected for presence S. aureus count, $32 \%$ rejected for presence of araerobic count and $24 \%$ rejected for presence of collforms count when compared with the relevant Egyptian Standard. ES 288/2005 (EOS, 2005). The dala also revealed that one can depend on smoking to minimize growth of spollage and/or pathogenic microorganisms. The data also indlcale that aboul $44 \%$ of the examuned samples were rejected microbiologically (S. aureus), while about $16 \%$ were rejected chemically ( $\mathrm{pH}$ and TVN) and about 7 to were rejected by sensory evaluation (Macer. ated and much macerated). So, one cannol depend upan sensory and chemlcal tests alone for detemination of hyglenis qually of smoked fish Recommendations $10 \mathrm{~lm}$. prove quallty and safety of smoked herring fish were discussed.
\end{abstract}

\section{INTRODUCTION}

Smoking is one of the oldest methods of preservauon. Long before. there were refrigerators and freezers; our fish ancestors learned to use a combinaton of salt and smoke to keep nsh away from spolling.

The objective of smoking of nsh was to increase the shelf life of the raw materials. Random smoking procedures are designed to impact the desired sensory characteristics to fish uniformiy and conslstency from batch to another (Footitt and Lewrls, 1999).

Srnoked fishes are usually eaten as seasonal diet among Egyptlan, particularly in the Easter Feast (Sham El-Nesseem). In the parucular season emergency measures werc taken every where 
all over the country to prevent and to treat a possible infection due to the consumption of anomalous amount of nshes in that particular feast day. Moreover. contsoversy about this issue are usually held annually. Just bciore and during thls season, regarding the posslble risks coming due to the consumption of salted and smoked fishes. Outbreaks are recorded every year due to polsoning, with some deaths, of admonish importance in this direction. and always the botullsm and the staphylococcal Intoxlcation werc the cause.

The Egyptian Standard, ES 288/2005 (EOS, 2005) stated that smoked ish product is that Bsh whlch had been prepared (headed, evtscerated. nlleted) and salted by Sodlum chlorde, and partially drted, then exposed to smokc, ivhlch produced by buming speclal type of wood or saw dust The smoke must penetate the meat tIssue to give final product with speclal calor, taste and odor. It is possible to avold the use or the smoking process by adding smoke flavoring mixtures to the flish.

The organolepuc quallty of smoked fish and nsli products (cooked fishes) recelved the attention of some insiders In the EC community (Howgate et al. 1992). The early work made by Shewan et al. (1953). and that reported by Wheaton and Lawson (1985); Connell (1995) and Rulter (1995) enable rates of spoilage to be n.easured in sensory terms and to make more preclse comparison as well as a nululingual guide to ficsliness giades.

Ideally. smoked fish should get its llavor and mahogany color from the smoke. but many cheaper smoked fish have smoke flavor as additives. Smoking process is considered as a sequel of curing. the result is dry. golden brown surface which is imperative. beside the wood smokes that are deposited on the fish products which inhlbit the development of spollage organisms and act as antioxdant, it is of prime interest to use the curing and smoking processes to increase the palatabully of the product which will meet the consumer acceplance and/or preferences (Frothier et al.. 1980).

The Egyptan Standard. ES 288/2005 (EOS, 2005) staled llsat the TVN should be less than $30 \mathrm{mg} \%$ and $\mathrm{pH}$ should be less than 6.8 .

Health hazards related to consumption of contaminated ish and fish products with enteropathogens involved in food polsoning cases, such enteropathogenlc bacteria Include Escherchla coll, Shigella spp.. Bacillus cereus, Vibro parahaemolytucus. ClostHdium perfringens. Salmonelia spp. and Listerla monocytogenes. Preventive sleps were laken by such organlaation as $\mathrm{FAO} /$ WHO were outined (BykowskJ, 1998).

Shigella and also Vibro parahaemolyticus was found in sea foods in the US assoclated iviu fecal contamination and causlng food born diseasc (Llpp and Rose, 1997) 
Glawalno and Segarra (1998) found that foodborne diseases and food polsoning usually arislng from consumption of ish contaminated by Clastridium perfingens.

Buchmann et al. (1999) stated that despite a low Incldence of botulism in the industrialized world. some cases occastonally occur in Gernany after caung contaminated food. Because bolulism is rarely seen, most physiclans are unfamlliar with its early recognition and treatment. However. immediate intenslve care treatment is important. The authors added that they reported the case of a previously 54-year old female who developed signs of botullsm after eating vacuum-packed smoked fish and developed sever respiratory insumclency with dimcult carbon dioxide ellmination in the days following.

Fell et al. (2000) reported an outbreak of Salmonella blockley infectlon following smoked eel consumption In Germany.

So, the present study was conducled to evaluate the sensory, cheinical and microblological conditions of smoked fish sold in relall market in Alexandrla governorate.

\section{MATERLAL AND METHODS}

Twenty nve random samples of smoked herring were collected from some supermarkets in Egypt. The samples were taken and transierred directly to the laboratory under aseptlc condlUons with a mindmum of delay. The samples were subjected to sensory. chemical. and microbio logical examinatlons

The methods of exnmination were carried out according to the following :

1. Sensory examlnation was carrted out according to Connell (1990)

2. Chemical examination includes:

2.1- pH value was cartled out accordlng the technique recommended by ISO (1979).

2. 2- TVN was done according the technlque recommended by FAO (1980).

3. Microblologlcal exarnination:

3.1- Determination or total bacterial count was performed according to ICMSF (1896).

3.2- Determination of total Collforms count was done using violet red blle agar according to APBA (1885).

3.3- Enumeration of presumptive Escherichla coll was camied out according to ISO (I894)11866.

3.4- Enumeration and Identuncation of Stapliylococcus aureus were performed according to 


\section{ICMSF (1896).}

3.5- Detection and enumeration of Listeria monocytogens was carried out according to iso (1995)-11290.

3.6- Detecton of Salmonella was carred out according to IŞo (1993)-6579.

3.7- Deternination of Lotal Mold and yeast count was done according to Balley and Scott (1998).

3.8- Determination of total aerobic sporeforming count was performed according to ICMSF (1996).

3.9- Determinatlon of wotal anaeroble sporeformlng count was cartled out according to ICMSF (1996).

3.10- Deternination of Vibrio parahaemulyticus was carried oul according to APRA (1992).

3.11- Enumeration of Clostrdium perfingens was carrted out according to ISO (1885)-7937.

\section{RESULTS AND DISCUSSION}

Table (1) revealed that the sensory examination of market smoked herring for skin condition indicate that $72 \%$ of samples ivere with accepted Intacl skin and $12 \%$ were with unaccepted macerated $3 k$ in while $4 \%$ were with much macerated skIn (this maceration may be due to using Imported frozen herring nsh whlch could be maceratcd during splitung and thawing of lash blocks or physical damage during handling, while examination of marketed smoked herring for skin color Indicate that $24 \%$ of samples were with golden brown color and $76 \%$ were with golden yellow color and no sample was recorded with dark brown or moldy growth (this Indicate completed and good smoking processes). wh:le examination of marketed smoked heming for consistency condluon Indicate that $76 \%$ of sampics were firm and $24 \%$ were friable and this may be due to high fat $\%$ or beginnlng of deterioration and no samples were soft or dry, and also examination of marketed smoked herring for flesh odor condition Indicate that $84 \%$ of the samples were considered as smoked hishy odor and $4 \%$ were musty odor and this may be due to beginning of deterioration. while examination of markeled smoked hering for Mesh taste condition Indicate that $84 \%$ of samples were with smoked inshy taste and $4 \%$ were with salty lasteldue to over use brine solution) and no sample was wth bitter or musty taste.

Nearly similar results were obtained by Daoud aod Abd El-Azziz (1996), Wafan (1999), Baeawroms et al. (2000) and El-Kewaley \{2001\}.

The data reported in table (2) Indicated that the minimum, maximum and mean values of $\mathrm{pH}$ 
on smoked herring fish were $5.8,7.2$ and $6.24 \pm 0.08$, respectuveiy $184 \%$ accepled and $16 \%$ were unaccepted $\mathrm{pH}$ Over 6.8). whlle the minimum, maxumum and mean values of TVN on examtned smoked hering ish were 18,48 and $25.99 \pm 1.68$, respecllvely $184 \%$ accepted $\%$ and $16 \%$ were unaccepted) (TVN Over $35 \mathrm{mg} \%$ ).

Nearly similar results were obtained by Saber et al. (1992), Daoud and Abd El-Azzlz (1006), Humetbloom et al. (1996) and Vishmanath et al. (1998). while higher results were obtalned by El-Kewaley $\{2001\}$.

The results recorded in table (3) revealed that the incidence of posluive samples appeared as minimum. maxlmum and mean values of total bacterlal count (CFU/ml) on smoked herring nsh were $25(100 \%), 2 \times 10^{2} ; 1.2 \times 10^{6}$ and $7.4 \times 10^{4} \pm 4.8 \times 10^{4}$. respectuvely; for Staphylococcus aureus count were 11 (44\%): $0: 6 \times 10^{4}$, and $9.1 \times 10^{3} \pm 3.9 \times 10^{3}$, respectively: for anaeroblc count were $20(80 \%), 0 ; 9 \times 10^{3}$. and $7.1 \times 10^{2} \pm 3.9 \times 10^{2}$, respectlvely while for mold and yeast count were $21(84 \%) .0: 5 \times 10^{3}$ and $6.7 \times 10^{2} \pm 2.3 \times 10^{2}$. respectively and also for Coliforms count were $6\left(24 \%\right.$ ). $0 ; 3.5 \times 10^{3}$ and $1.6 \times 10^{2} \pm 1.4 \times 10^{2}$. respectlvely smally for sporeforming count were $50(100 \%) .8 \times 10 ; 2 \times 10^{4}$, and $2.3 \times 10^{3} \pm 1.1 \times 10^{3}$. respectively. C. perfingens, E. coll. Salmonella, Listerta monocytogenes, and Vibrio parahaemolyticus could not be detected. The data also indicate that there were $16 \%$ of samples rejected for higher total bacterial count: $44 \%$ were rejected for presence $S$, aureus count: $32 \%$ were rejected for presence of anaerobic count and $24 \%$ were rejected for presence of Collforms counl according to the EgypUan Standard. ES $288 / 2005$ (EOS, 2005).

The presence of contaminated and pathogenic nicroorganism may be due to poor handling and /or improper storage methods and may be also due to poor personal hyglene and lake of sanitation during processing

The data also indicale thal one can depend on smoking to prevent growth of spollage and/or pathogenlc microorganlsms. The data also indicate there are about $44 \%$ of samples were rejected microblologically (S. aureus), whlle about $16 \%$ were rejected chemically (ph and TVN) and about 7\% were rejected by sensory evaluation (Macerated and much macerated). So, depending upon sensory and chemucal tests alone on determinlng hygienle quality of smoked $n$ sh is not always acceptable.

Nearly simllar results were obtalned by Dodds et al. (1992). El-Shater (1994) and ElKemaley (2001). Higher results were obtalned by Daoud and Abd El-Azziz (2896), Edris (1896) and Basamrows et al. (2000).

Strtct hygenic measures should be laken during different stages of handling, transportation, storage. processing and marketing of smoked fish. The Egyptan nsh industry needs, highly. to 
Abd El-Faficz, E. M. E' \& Amang, H. Salem

follow the requirements of rIACCP system or the more recent. Food Safety Managernent Sysiem. ISO 22000:2005. 
Table (1): Statistical snalytical results of sensory examination of Smoked Herning fish $(n=25)$.

\begin{tabular}{|c|c|c|c|c|c|c|c|c|c|c|c|c|c|c|c|c|}
\hline \multicolumn{3}{|c|}{ Skin condition } & \multicolumn{4}{|c|}{ Skin colour } & \multicolumn{4}{|c|}{ Consistency } & \multicolumn{2}{|c|}{ Flesh odour } & \multicolumn{4}{|c|}{ Flesh taste } \\
\hline Intact & Macerated & $\begin{array}{c}\text { much } \\
\text { macerated }\end{array}$ & $\begin{array}{l}\text { Golden } \\
\text { brown }\end{array}$ & $\begin{array}{l}\text { Golden } \\
\text { yellow }\end{array}$ & $\begin{array}{l}\text { Dark } \\
\text { browm }\end{array}$ & $\begin{array}{l}\text { Mouldy } \\
\text { growth }\end{array}$ & Fim & Friable & Sort & Dry & $\begin{array}{l}\text { Smoked } \\
\text { lishy }\end{array}$ & Musty & $\begin{array}{l}\text { Sinokd } \\
\text { fishy }\end{array}$ & Salty & Bitter & Musty \\
\hline 18 & 3 & 4 & 6 & 19 & 0 & 0 & 19 & 6 & 0 & 0 & 21 & 4 & 21 & 4 & $a$ & 0 \\
\hline $72 \%$ & $12 \%$ & $16 \%$ & $24 \%$ & $76 \%$ & $.0 \%$ & $0 \%$ & $76 \%$ & $24 \%$ & $0 \%$ & $0 \%$ & $84 \%$ & $16 \%$ & $84 \%$ & $16 \%$ & $0 \%$ & $0 \%$ \\
\hline
\end{tabular}

Table (2): Statistical analytical results of chemical examination of Smoked Herring fish ( $n=25)$.

|

面 


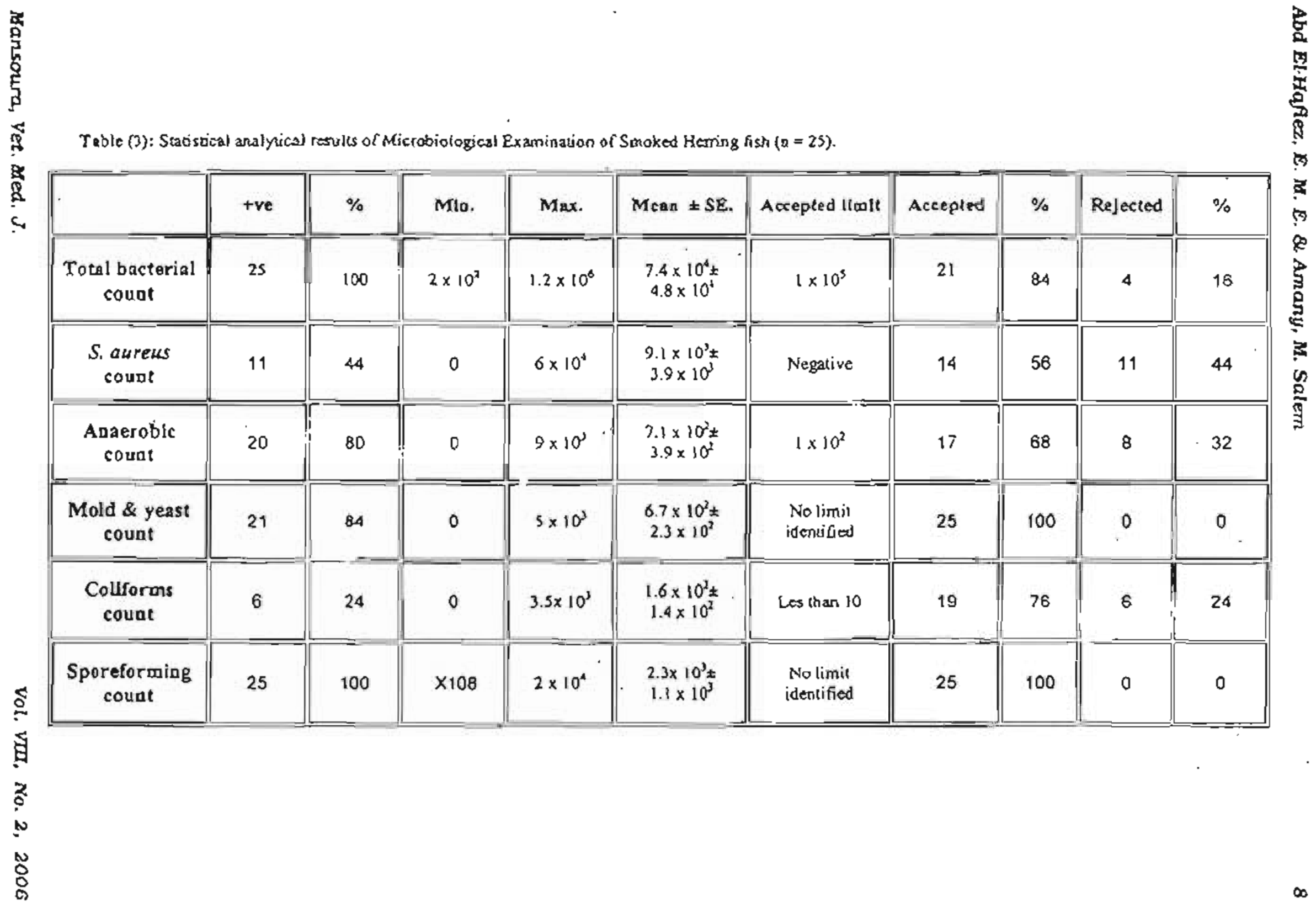




\section{REFERENCES}

APHA (1985) : Standard Methods for the examination of Dalry products. 15 th Ed.. American Public Health Association. New York.

APHA. American Publle Health Assoclation (1992) : Compendium methods for the mlcroblologlcal examination of foods, $3^{\text {rd }}$ Ed. Washington. D.C.. USA

Balley, w. R. and Scott, E. G. (1998) : Diagnostic Microblology. A Textbook for the 1solation and identincation of pathogenic Microorganlsms. The C.V. Mosby Company, Saint Louls.

Bastawrows, A. F.; Abo-EI-Alla, A. A; Sayed, A. M. and Abd El-Sater, M. A. (2000) : Microblo- logical quality of smoked heming fish in Asslut City. Asslut Vet. Med. J. 43(85):110-123.

Buchmann. T.; Kabatnik, M.; Sander, A and peters, J. (1999) : Botulism with respiratory Insuffclency requining extra corporeal carbon dloxlde removal. Eur. J. Anaesthesiol 16 (5):346-349.

Bykopskd. P. J. (1898) : Health hazards related to consumpton of fish and fish products. Przemysl Spozyrvezy 52(7):13-16.

Conneli, J. J. (1990) : Control of Ash qualty. $3^{\text {rd }}$ Ed., Blackwell Scientific Publications, Oxford. PP. 85-88, $97-103$.

Daoud, Johan, R. and Abd E1-Azzix A. T. (1996) : Sensory, bacterlal, parasitic and chemical evaluatuon of smoked fishes (Herning) in El-Sharkia govemorate. Egypt. Agric. Res. 79 \{4\}: 1047-1055.

Dodds, KC L.; Brodsky, M. H. and Warburton, D. W. (1992) : A retall survey of smoked ready to eat nsh to determine their microblologlcal quallty. J. Food Prot. 55(3):208-210.

Edris, A M. (1896) : Microblal evaluation of some marketed smoked ish. Zagazig Vet. J. 24 (1):76-81.

El-Shater. M. A. H. (1994) : Quality Investgadon into locally produced smoked Ash. Ph. D. Thesis, Fac. Vet. Med., Calro University.

El-Kemalog, I. A (2001) : Quality assessment of some locally manufactured and retailed meat and Ish products. Ph. O. Thesis. Fac. Vet. Med., Tanla Unlversity.

EOS, Egyptian Organization for Standardization and quality (2005) : Egypuan Slandard, ES 288/2005, smoked fish.

FAO, Foad and Agriculture Organization of the united nation (1980): Manual of food quality 
control. 3-Commodities. United Nations, Rome.

Fell, G.; Hamouda, O.; Linder.R.; Rehmet, S.; Llesegang, A.; Prager, R.; Gericke, B. and Petersen, L. (2000): An outbreak of Salmonella blockly infection followed smoked eel consumption in Germany. Epidemtol. Infect. 125(1):9-12.

Footitt, R. J. and Lewis, A. S. (1999) :-The canning of fish and meat. Bladcle academic and professlonal, London, Glasgow, Wetnhelm. New York, Tokoyo, Melbourne, Madras.

Fretheim, K.; Granum, P. E. and Vold, E. (1980) : Influence of generation temperature on the chemical composition, antioxidative and antimicrobial effects of wood smoke. J. Food Scl. 45:999-1002.

Glameno, G. R. M. and Segarra, S. P. J. (1998) : Health risks from fish and shellßsh, bacterial infection and poisoning. Alimentarle. 293:93-96.

Himelbloom. B. H.; Crapo, C. A. and peutzenreuter, R. C. (1996) : Microblal quallty of an Alaska native smoked salmon process. J. Food Prot. 59(1):56-58.

Howgate, P.; Johnston, H. and Whittle, K. J. (1992) : Multilingual gulde to EC freshness grades for flshery products. Torry Researcl Station, Aberdeen. 32Pp.

ICMSF (1996) : Microorganisms in foods, Vol.1, their signiflance and methods of enumeration, 2nd Ed. Univ. Toronto Press. Toronto, Canada.

ISO (1979) : International standards. ISO-2917. Meat and meat products: Measurement of pH (Reference method).

ISO (1985) : Microblology -general guldance for enumeration of Clostridium perfringens-colony count technique. 1SO 7937.

ISO (1993) : General guldance on methods for detection of Salmonella, ISO 6579:1993 (E).

ISO (1994): MIlk and Milk producls: Enumeration of presumptive Escherichia coll. ISO /D. 11866.

Iso (1995) : Horizontal method for the detection and enumeration of Listerla monocytogenes. 1SO/DIS 11290-1.

Llpp, E. K. and Rose, J. B. (1997) : The role of sea food in foodborne diseases in the United State of America. Revuc Scientifque et Technique Omce International des Eplzooties. $16(2): 620-640$.

Ruiter, A. (1995) : Fish and Fishery products: Composition, nutrituve propertles and stability. $\mathrm{CAB}$ International.

Mansoura, Vet. Med. J.

Vol. VII. No. 2, 2006 
Saber, Nadia, M. Nahed, M. El-Shemal and Botlt. S. M. (1992): Quality ateributed of smoked fish products locally produced in Alexandria. J. Agrt. Scl., Mansoura Unlv. 17(4):838846.

Shewan. J. M.; Macintosh, R. G.; Tucker, C. G. and Ehrenberg, A. S. C. (1953) : The development of numerical scoring system for the sensory assessment of the spollage of wet white Iish stored in Ice. Journal of the Science of Food and Agriculture 4:283-298.

Vishwanath, W.; Lllabat1, H. and Bljen, M. (1998) : Blochemical,nutrillonal and microblologjcal quality of fresh and smoked mud eel fosh (Monoplerus ajous) - a comparative study. Food Chem. 61(1/2):153-156.

Wafaa. F. A. (1999) : mlcroblological aspects of smoked fishes at retall outlets. M. V. Sc. Thesis, Fac. Vet. Med., Zagazig Unlversity.

Wheaton, F. W. and Lawson, T. B. (1985) : processing aquatic food products. Jolin Wlley and $\because \quad$ Sons. New York. 


$$
\begin{aligned}
& \text { الملخص العيىى }
\end{aligned}
$$

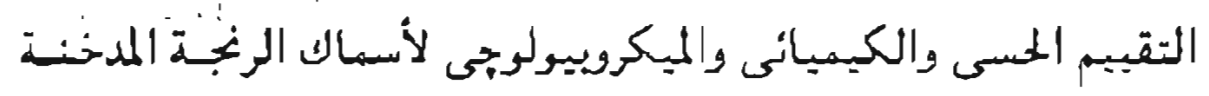

$$
\begin{aligned}
& \text { أمانى محهد سالم السيليد عبدا الحفيظ }
\end{aligned}
$$

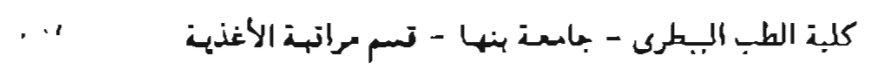

$$
\begin{aligned}
& \text { مركز بحسوث صسن الحيسولن فرع الإسكندية }
\end{aligned}
$$

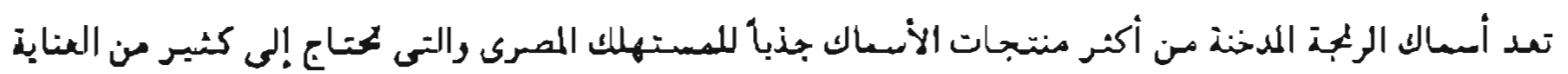

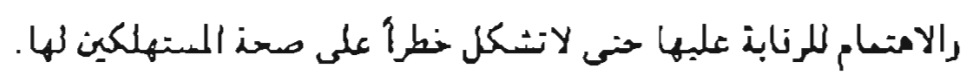

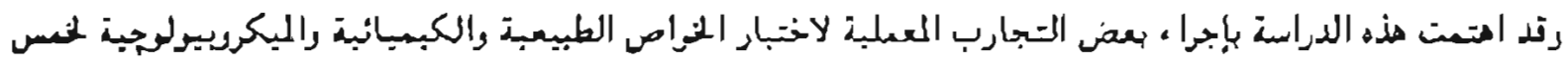

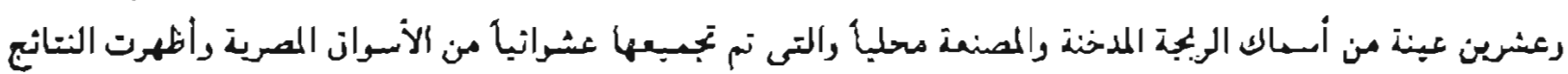

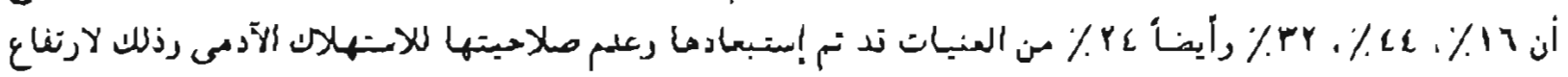

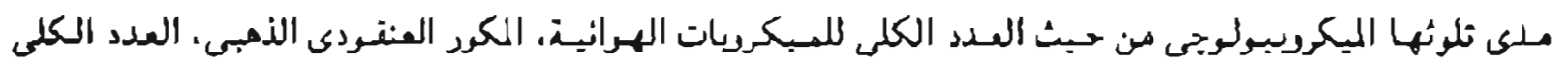

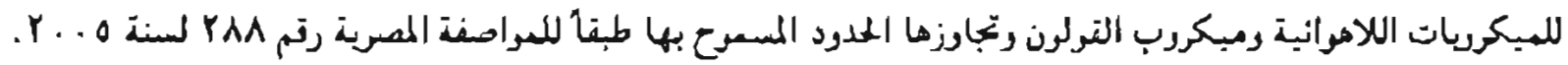

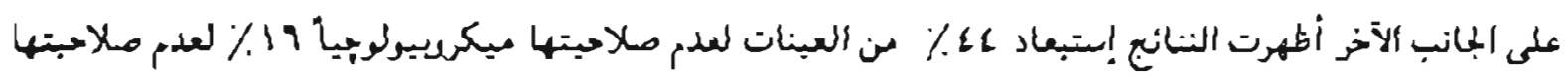

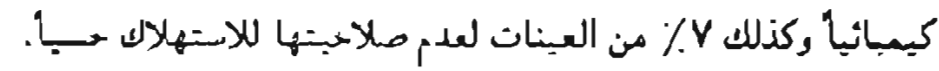

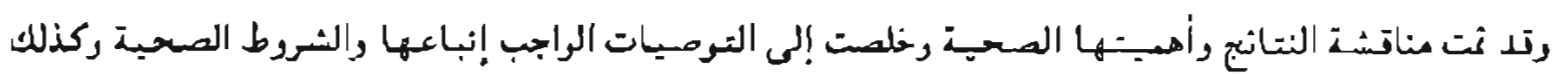

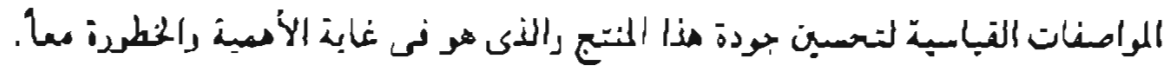

